\title{
Comparison of Antibiotic Resistance of Udder Pathogens in Dairy Cows Kept on Organic and on Conventional Farms
}

\author{
M. Roesch, ${ }^{* 1,2}$ V. Perreten, $\dagger^{1}$ M. G. Doherr, $\neq^{1}$ W. Schaeren, $\S$ M. Schällibaum,§ and J. W. Blum ${ }^{* 3}$ \\ *Division of Nutrition and Physiology, Institute of Animal Genetics, Nutrition and Housing, \\ †Institute of Veterinary Bacteriology, and \\ ‡Department of Clinical Veterinary Medicine, Vetsuisse Faculty, University of Bern, $\mathrm{CH}-3012$ Bern, Switzerland \\ $\S$ Swiss Federal Research Station for Animal Production and Dairy Products, CH-3097 Liebefeld-Bern, Switzerland
}

\begin{abstract}
There has been a rapid rise in the emergence of multidrug-resistant pathogens in the past 10 to $15 \mathrm{yr}$ and some bacteria are now resistant to most antimicrobial agents. Antibiotic use is very restricted on Swiss organic dairy farms, and a purely prophylactic use, such as for dry cow mastitis prevention, is forbidden. A low prevalence of antibiotic resistance in organic farms can be expected compared with conventional farms because the bacteria are infrequently or not exposed to antibiotics. The occurrence of antibiotic resistance was compared between mastitis pathogens (Staphylococcus aureus, nonaureus staphylococci, Streptococcus dysgalactiae, Streptococcus uberis) from farms with organic and conventional dairy production. Clear differences in the percentage of antibiotic resistance were mainly species-related, but did not differ significantly between isolates from cows kept on organic and conventional farms, except for Streptococcus uberis, which exhibited significantly more single resistances (compared with no resistance) when isolated from cows kept on organic farms (6/10 isolates) than on conventional farms $(0 / 5$ isolates). Different percentages were found (albeit not statistically significant) in resistance to ceftiofur, erythromycin, clindamycin, enrofloxacin, chloramphenicol, penicillin, oxacillin, gentamicin, tetracycline, and quinupristin-dalfopristin, but, importantly, none of the strains was resistant to amoxicillin-clavulanic acid or vancomycin. Multidrug resistance was rarely encountered. The frequency of antibiotic resistance in organic farms, in which the use of antibiotics must be very restricted, was not different from conventional farms, and was contrary to expectation. The antibiotic resistance status needs to be monitored in organic farms
\end{abstract}

Received August 4, 2005

Accepted October 19, 2005.

${ }^{1}$ These authors contributed equally to this work.

${ }^{2}$ Present address: Clinic for Ruminants, Veterinary Faculty, Ludwig-Maximilian University of Munich, Sonnenstrasse 16, D-85764 Oberschleissheim.

${ }^{3}$ Corresponding author: juerg.blum@itz.unibe.ch as well as conventional farms and production factors related to the absence of reduced antibiotic resistance in organic farms need to be evaluated.

Key words: organic dairy production, mastitis, antibiotic resistance, dairy cow

\section{INTRODUCTION}

There has been an acceleration in the emergence of multidrug resistant pathogens in the past 10 to $15 \mathrm{yr}$ (Shea, 2003). Today, some bacteria are resistant to most antimicrobial agents, which provides a growing problem in humans and in veterinary medicine (Levy, 1998). Observations suggest that the use of antibiotics in animal husbandry is a driving force for the development of antibiotic resistance in certain pathogenic bacterial species (Bates et al., 1994; Witte, 1998).

Most (90 to 95\%) conventional Swiss dairy farms work using guidelines of integrated production (IP). The general goals are not only economical success, but also sustainability of production, protection of soil, water, air, landscape, and nature. In these dairies, treatments for clinical and subclinical IMI as well as mastitis prevention with dry cow therapy are mostly performed by use of antibiotic agents. For dry cow therapy use of long-acting antibiotics is recommended as the most effective means to eliminate existing infections and to prevent new ones (Eberhart, 1986). Antibiotics of the classes cephalosporins (cefacetril, cefalexin, cefapirin, cefoperazon), aminoglycosides (gentamicin, neomycin, kanamycin), macrolides (spiramycin), lincosamides (lincomycin), $\beta$-lactams (amoxicillin, cloxacillin, penicillin), and $\beta$-lactam combined with $\beta$-lactamase inhibitor (amoxicillin-clavulanic acid) are authorized in Switzerland for the prevention and treatment of mastitis in dairy cows in IP farms. Any use of antibiotics leads to a higher risk of resistance selection (Moellering, 1990; Chaslus-Dancla et al., 2000). Treatments for IMI, if performed by farmers themselves, are often not done in accordance with the recommendations for the used antibiotics with regard to amount and duration. A subtherapeutic level of antibiotics administered in 
dairy cows may especially select for antibiotic-resistant bacteria (Falkow and Kennedy, 2001). The existence of antibiotic resistance of udder pathogens is worldwide as is shown by recent studies in New Zealand and Denmark (Salmon et al., 1998), the United States (Rossitto et al., 2002), and Finland (Pitkälä et al., 2004). Although antibiotic resistance patterns may reflect the antibiotics used for mastitis prevention and treatment in some studies (Rajala-Schultz et al., 2004), convincing evidence is lacking that the use of antibiotics for the treatment or prevention of mastitis has resulted in development of resistance to these antibiotics (Hillerton and Berry, 2005). Thus, in studies performed in the United States, there was no indication of increased resistance to antimicrobials that are commonly used in dairy cattle for treatment of mastitis (Erskine et al., 2001; Makovec and Ruegg, 2003). De Oliveira et al. (2000) found only a low level of antibiotic resistance of bovine mastitis pathogens from Europe and the United States. In Switzerland, there was no increase of antibiotic resistance of mastitis pathogens during the last 20 yr (Corti et al., 2003). A recent review found no evidence that antibiotic therapy has led to a problem of resistance in mastitis-causing bacteria (NMC, 2004). A Belgian study suggests that the proportion of mastitiscausing Staphylococcus aureus strains resistant to penicillin $\mathrm{G}$ has declined over the years from 80 to $50 \%$ (Devriese et al., 1997). Typical bacterial species that cause mastitis in dairy cows have few, if any, mechanisms for transfer of resistance to other bacteria, as occurs with intestinal bacteria.

In Swiss dairies with organic production (OP), therapeutic interventions should be based on alternative methods. The prophylactic use of allopathic drugs or antibiotics is forbidden. It is well known that the therapeutic use of antibiotics should be limited and based on prescription by a veterinarian. For cases of mastitis in OP farms, antibiotics like penicillin, cloxacillin, gentamicin, and neomycin may be used. Because antibiotic use should be low or absent, antibiotic resistance of udder pathogens should not be expected in OP farms or be at least at a lower level than in conventional farms. A lower prevalence of antibiotic resistance of Staphylococcus aureus strains was found on OP than on conventional farms in the United States (Tikofsky et al., 2003). However, Sato et al. (2004) found only small differences between OP and conventional farms in the United States and Denmark.

In a Swiss study of cows with chronic mastitis, kept on OP farms, neomycin resistance of streptococci was very high (94\%) and gentamicin resistance of streptococci appeared higher than in conventional farms (75 and $3 \%$, respectively), whereas resistance percentages of coagulase-negative staphylococci (with the exception of resistance to rifamycin) and of Staphylococcus aureus were similar (Busato et al., 2000). However, antibiotic resistance status was not simultaneously investigated in conventional farms. The antibiotic resistance status of mastitis pathogens isolated from cows kept on OP farms and on IP farms for only Staphylococcus aureus strains isolated from OP and IP farms has been reported (Tikofsky et al., 2003; Sato et al., 2004). To our knowledge, the present study is the first epidemiological study that compares the antibiotic resistance status of several mammary gland pathogens isolated from OP and IP farms using different approaches for mastitis treatment.

\section{MATERIALS AND METHODS}

\section{Selection of Cows and Collection of Milk Samples}

The selection of farms and cows is described in detail in Roesch (2004) and Roesch et al. (2005). In short, 60 certified OP farms with at least $3 \mathrm{yr}$ of organic farming were randomly selected from a pool of interested OP farms within the canton of Bern, Switzerland. Sixty IP farms, from a pool of interested farms, were selected based on their geographic proximity (ZIP code) to the OP farms; that is, the same agricultural zone (elevation) and farm size (number of cows) as the neighboring farm. Farm visits began in June 2002 and were finished in May 2003. On each farm, between 5 and 13 dairy cows (depending on farm size) were randomly selected at 31 d (median) postpartum. In total, 483 OP cows and 487 IP cows were tested.

The median age of cows in this study was $5.3 \mathrm{yr}(3.2$ to $10.9 \mathrm{yr})$ for OP cows and $5.2 \mathrm{yr}(3.1$ to $11 \mathrm{yr}$ ) for IP cows. The Simmental $\times$ Red Holstein crossbreed was found in 87 and $75 \%$ of OP and IP farms, respectively. Purebred Holstein cows were in 45 and $60 \%$, purebred Simmental cows in 40 and 37\%, and other breeds (Swiss Brown Cattle, Montbéliard, and Jersey) in 7 and 10\% of OP and IP farms, respectively. More than one breed was kept in $70 \%$ of OP farms and $72 \%$ of IP farms. The differences in breed composition and cow age were not significant between production systems.

The California Mastitis Test (CMT) was performed at $31 \mathrm{~d}$ postpartum on each quarter after udder sanitation, appraisal, and discarding of foremilk. The CMT results were interpreted as $0+$ (negative), 1+ (traces), 2+ (gel), and 3+ (clumps, highly viscous, discarding in portion no longer possible). Quarters with a $\mathrm{CMT} \geq 1+$ reaction, but without any clinical signs of mastitis, were considered subclinical IMI. Milk samples from quarters diagnosed with a CMT $\geq 2+$ reaction were collected aseptically, immediately cooled on ice, frozen on the day of collection, and stored at $-20^{\circ} \mathrm{C}$ until processed (once per month) for bacterial culture and analysis. Milk samples 
from cows treated with antibiotics at the time of the collection and up to $7 \mathrm{~d}$ before collection and samples from cows with clinical mastitis were excluded. Individual test-day SCC (measured in accordance with the FIL-IDF standard 148A; IDF, 1995) were made available from the Swiss Simmental and Red and White Cattle Breeding Association (Zollikofen), from the Swiss Brown Cattle Breeder Federation (Zug), and from the Swiss Holstein Breeding Association (Posieux). Data of the official milk measurement used were those closest in time to the day of our cow visit. The association between the number of quarters positive per cow for the CMT (CMT $\geq 1+)$ and the composite sample SCC were evaluated graphically (geometric SCC means over the number of positive quarters) and by simple linear regression.

Only isolates of Staphylococcus aureus, nonaureus staphylococci (coagulase-negative Staphylococcus spp.), Streptococcus uberis, or Streptococcus dysgalactiae were tested for antimicrobial resistance. For cows with 2 or more subclinically infected quarters with the same bacteriological findings (same species), only one isolate was used for the antimicrobial resistance test. Thus, for each bacterial agent, the calculated prevalence based on quarter milk samples reflects the cow-level prevalence.

\section{Isolation and Identification of Udder Pathogens}

The bacteriological examinations of the milk samples were performed using standard procedures according to the guidelines of the National Mastitis Council (NMC, 1999). Aliquots of $10 \mu \mathrm{L}$ were streaked on blood agar plates and incubated aerobically at $37^{\circ} \mathrm{C}$ for 24 to 48 $\mathrm{h}$. The isolates were presumptively identified by Gram staining or potassium hydroxide tests. Staphylococci and streptococci were differentiated by catalase activity. The staphylococci were further identified based on coagulase activity, DNAse activity, and pigment production as Staphylococcus aureus or nonaureus Staphylococcus spp. The streptococci were identified to species level using Rapid ID 32 STREP (BioMérieux, Marcy l'Etoile, France) using cells grown anaerobically for 24 $\mathrm{h}$ at $37^{\circ} \mathrm{C}$ according to the instructions of the manufacturer.

\section{Antimicrobial Resistance Tests}

The minimal inhibitory concentrations of erythromycin, ceftiofur, clindamycin, chloramphenicol, enrofloxacin, gentamicin, tetracycline, vancomycin, oxacillin, penicillin, and the combinations quinupristin-dalfopristin and amoxicillin-clavulanic acid were determined in Mueller-Hinton broth for staphylococci, and in Mueller-Hinton broth supplemented with 5\% horse blood (Oxoid Ltd., Basingstoke, UK) for streptococci using custom sensititre susceptibility plates (Trek Diagnostics Systems, East Grinstead, UK; MCS Diagnostics BV, J. L. Swalmen, The Netherlands), and according to guidelines of the Clinical and Laboratory Standards Institute (CLSI, 2002). The breakpoints determining resistance were those recommended in the CLSI guidelines M31-A2 (CLSI, 2002) and M7-A6 (CLSI, 2003). Strains showing intermediate category were classified as resistant (Tables 1 to 4). Only staphylococci, not streptococci, were tested for resistance to oxacillin.

\section{Statistical Analyses}

Results of SCC were presented as geometric means and $95 \%$ confidence interval (CI; geometric mean \pm 1.96 $\times$ SEM). Somatic cell count data between independent groups were compared using the Wilcoxon Rank-Sum Test. Resistances (present or absent) by production type, bacterial species, and antibiotic substance were described using frequencies and proportions. The Fisher's Exact Test evaluated the hypothesis that the 2 column percentages in a $2 \times 2$ table are equal. It is especially useful when sample sizes are small (zero in some cells) and when the $\chi^{2}$ test is not appropriate. Fisher's Exact Test was used to compare the observed proportions of antibiotic resistances for each agentsubstance combination between isolates from cows held on OP and IP farms. All statistical analyses were performed with the statistical software NCSS 2001 (www.ncss.com). The overall level of statistical significance was set to $P<0.05$.

\section{RESULTS}

\section{California Mastitis Tests and Somatic Cell Counts}

On d 31 of lactation, the proportion of OP and IP farms with at least one cow with a CMT-positive quarter $(\mathrm{CMT}>1+)$ was identical (93 and 93\%, respectively) and the percentage of cows with at least one CMTpositive quarter was similar (39.4 and $34.2 \%$, respectively). There was a higher percentage of cows with at least one quarter showing a CMT $\geq 2+$ reaction $(P<$ $0.001)$ in OP than IP farms (10.3 and $7.2 \%$, respectively). The geometrical mean of SCC from composite milk samples from OP cows with at least one CMTpositive quarter $\left(90 \times 10^{3}\right.$ cells $/ \mathrm{mL}$; $95 \%$ CI: 71 to $115 \times$ $10^{3}$ cell $/ \mathrm{mL}$ ) was higher, but not significantly different from that of IP cows $\left(73 \times 10^{3}\right.$ cells $/ \mathrm{mL}$; $95 \%$ CI: 57 to $93 \times 10^{3}$ cell $\mathrm{s} / \mathrm{mL}$ ). The SCC of composite milk samples increased linearly $\left(\mathrm{r}^{2}=0.95 ; P=0.003\right)$ with increasing numbers of CMT-positive quarters. The geometrical mean of SCC of healthy cows (all 4 quarters CMT- 
Table 1. Antibiotic resistance of Staphylococcus aureus strains isolated from quarters with subclinical mastitis (California Mastitis Test $\geq 2$ ) at d 31 postpartum in 60 farms with organic production (OP) and 60 farms with integrated production (IP) ${ }^{1}$

\begin{tabular}{|c|c|c|c|c|c|c|c|}
\hline \multirow[b]{2}{*}{ Antibiotic substance } & \multicolumn{2}{|c|}{$\begin{array}{l}\text { Breakpoints }^{2} \\
(\mu \mathrm{g} / \mathrm{mL})\end{array}$} & \multicolumn{2}{|c|}{$\begin{array}{l}\text { OP cows } \\
(\mathrm{n}=46)^{3}\end{array}$} & \multicolumn{2}{|c|}{$\begin{array}{l}\text { IP cows } \\
(\mathrm{n}=33)^{3}\end{array}$} & \multirow[b]{2}{*}{$P^{5}$} \\
\hline & Intermediate & Resistant & No. ${ }^{4}$ & $\%$ & No. ${ }^{4}$ & $\%$ & \\
\hline Amoxicillin-clavulanic acid (2:1) & - & $\geq 8 / 14$ & 0 & 0.0 & 0 & 0.0 & 1 \\
\hline Ceftiofur & 4 & $\geq 8$ & 1 & 2.2 & 0 & 0.0 & 1 \\
\hline Chloramphenicol & 16 & $\geq 32$ & 9 & 19.6 & 2 & 6.1 & 0.11 \\
\hline Clindamycin & 1 to 2 & $\geq 4$ & 2 & 4.3 & 0 & 0.0 & 0.51 \\
\hline Enrofloxacin & 1 to 2 & $\geq 4$ & 3 & 6.5 & 2 & 6.1 & 1 \\
\hline Erythromycin & 1 to 4 & $\geq 8$ & 4 & 8.7 & 0 & 0.0 & 0.14 \\
\hline Gentamicin & 8 & $\geq 16$ & 5 & 10.9 & 2 & 6.1 & 0.69 \\
\hline Oxacillin & - & $\geq 4$ & 3 & 6.5 & 0 & 0.0 & 0.26 \\
\hline Penicillin & - & $\geq 0.25$ & 6 & 13.0 & 1 & 3.0 & 0.23 \\
\hline Quinupristin-dalfopristin & 2 & $\geq 4$ & 1 & 2.2 & 0 & 0.0 & 1 \\
\hline Tetracycline & 8 & $\geq 16$ & 1 & 2.2 & 0 & 0.0 & 1 \\
\hline Vancomycin & 8 to 16 & $\geq 32$ & 0 & 0.0 & 0 & 0.0 & 1 \\
\hline
\end{tabular}

${ }^{1}$ Per cow, only one isolate of the same bacterial species was tested.

${ }^{2}$ The breakpoints determining resistance were those recommended in the CLSI (Clinical and Laboratory Standards Institute) guidelines M31-A2 (CLSI, 2002) and M7-A6 (CLSI, 2003). Strains showing intermediate category were classified as resistant.

${ }^{3}$ Number of cows with Staph. aureus.

${ }^{4}$ Number of strains with antibiotic resistance.

${ }^{5}$ Significance levels of difference between cows in OP and farms with IP in the study from the Fisher's Exact Test statistic.

negative) was $26 \times 10^{3}$ cells $/ \mathrm{mL}$ ( $95 \%$ CI: 24 to $28 \times 10^{3}$ cells), whereas cows with $1,2,3$, or all 4 quarters with CMT-positive reactions had geometrical means of 81 (69 to 96 ), 190 (145 to 248 ), 215 (133 to 347 ), and 273
(113 to 655$) \times 10^{3}$ cells $/ \mathrm{mL}$, respectively, in the composite sample. The geometrical mean of SCC of cows with $1,2,3$, or 4 quarters with $\mathrm{CMT} \geq 2+$ ranged from 125 to $566 \times 10^{3}$ cells $/ \mathrm{mL}$.

Table 2. Antibiotic resistance of nonaureus Staphylococcus spp. strains isolated from quarters with subclinical mastitis (California Mastitis Test $\geq 2$ ) at d 31 postpartum in 60 farms with organic production (OP) and 60 farms with integrated production (IP) ${ }^{1}$

\begin{tabular}{|c|c|c|c|c|c|c|c|}
\hline \multirow[b]{2}{*}{ Antibiotic substance } & \multicolumn{2}{|c|}{$\begin{array}{l}\text { Breakpoints }{ }^{2} \\
(\mu \mathrm{g} / \mathrm{mL})\end{array}$} & \multicolumn{2}{|c|}{$\begin{array}{l}\text { OP cows }^{3} \\
(\mathrm{n}=19)\end{array}$} & \multicolumn{2}{|c|}{$\begin{array}{l}\text { IP cows }{ }^{3} \\
(\mathrm{n}=19)\end{array}$} & \multirow[b]{2}{*}{$P^{5}$} \\
\hline & Intermediate & Resistant & No. $^{4}$ & $\%$ & No. ${ }^{4}$ & $\%$ & \\
\hline Amoxicillin-clavulanic acid $(2: 1)$ & - & $\geq 8 / 4$ & 0 & 0.0 & 0 & 0.0 & 1 \\
\hline Ceftiofur & 4 & $\geq 8$ & 0 & 0 & 0 & 0 & 1 \\
\hline Chloramphenicol & 16 & $\geq 32$ & 2 & 10.5 & 0 & 0.0 & 0.49 \\
\hline Clindamycin & 1 to 2 & $\geq 4$ & 1 & 5.3 & 1 & 5.3 & 1 \\
\hline Enrofloxacin & 1 to 2 & $\geq 4$ & 0 & 0.0 & 0 & 0.0 & 1 \\
\hline Erythromycin & 1 to 4 & $\geq 8$ & 0 & 0.0 & 1 & 5.3 & 1 \\
\hline Gentamicin & 8 & $\geq 16$ & 1 & 5.3 & 0 & 0.0 & 1 \\
\hline Oxacillin & - & $\geq 0.5$ & 5 & 26.3 & 8 & 42.1 & 0.50 \\
\hline Penicillin & - & $\geq 0.25$ & 6 & 31.6 & 9 & 47.4 & 0.51 \\
\hline Quinupristin-dalfopristin & 2 & $\geq 4$ & 1 & 5.3 & 0 & 0.0 & 1 \\
\hline Tetracycline & 8 & $\geq 16$ & 1 & 5.3 & 0 & 0.0 & 1 \\
\hline Vancomycin & 8 to 16 & $\geq 32$ & 0 & 0.0 & 0 & 0.0 & 1 \\
\hline
\end{tabular}

${ }^{1}$ Per cow, only one isolate of the same bacterial species was tested.

${ }^{2}$ The breakpoints determining resistance were those recommended in the CLSI (Clinical and Laboratory Standards Institute) guidelines M31-A2 (CLSI, 2002) and M7-A6 (CLSI, 2003). Strains showing intermediate category were classified as resistant.

${ }^{3}$ Number of cows with nonaureus Staphylococcus spp.

${ }^{4}$ Number of strains with antibiotic resistance.

${ }^{5}$ Significance levels of difference between cows in OP and farms with IP in the study from the Fisher's Exact Test statistic. 
Table 3. Antibiotic resistance of Streptococcus uberis strains isolated from quarters with subclinical mastitis (California Mastitis Test $\geq 2$ ) at d 31 postpartum in 60 farms with organic production (OP) and 60 farms with integrated production (IP) ${ }^{1}$

\begin{tabular}{|c|c|c|c|c|c|c|c|}
\hline \multirow[b]{2}{*}{ Antibiotic substance } & \multicolumn{2}{|c|}{$\begin{array}{l}\text { Breakpoints }^{2} \\
(\mu \mathrm{g} / \mathrm{mL})\end{array}$} & \multicolumn{2}{|c|}{$\begin{array}{l}\text { OP cows }^{3} \\
(\mathrm{n}=19)\end{array}$} & \multicolumn{2}{|c|}{$\begin{array}{c}\text { IP cows }{ }^{3} \\
(\mathrm{n}=9)\end{array}$} & \multirow[b]{2}{*}{$P^{5}$} \\
\hline & Intermediate & Resistant & No. ${ }^{4}$ & $\%$ & No. ${ }^{4}$ & $\%$ & \\
\hline Amoxicillin-clavulanic acid $(2: 1)$ & $16 / 8$ & $\geq 32 / 16$ & 0 & 0.0 & 0 & 0.0 & 1 \\
\hline Ceftiofur & 4 & $\geq 8$ & 0 & 0.0 & 0 & 0.0 & 1 \\
\hline Chloramphenicol & 8 & $\geq 16$ & 3 & 15.8 & 1 & 11.1 & 1 \\
\hline Clindamycin & 0.5 & $\geq 1$ & 2 & 10.5 & 0 & 0.0 & 0.55 \\
\hline Enrofloxacin & 1 to 2 & $\geq 4$ & 8 & 42.1 & 2 & 22.2 & 0.42 \\
\hline Erythromycin & 0.5 & $\geq 1$ & 2 & 10.5 & 0 & 0.0 & 0.55 \\
\hline Gentamicin & 8 & $\geq 16$ & 10 & 52.6 & 3 & 33.3 & 0.44 \\
\hline Penicillin & 0.25 & $\geq 4$ & 1 & 5.3 & 1 & 11.1 & 1 \\
\hline Quinupristin-dalfopristin & 2 & $\geq 4$ & 1 & 5.3 & 0 & 0.0 & 1 \\
\hline Tetracycline & 4 & $\geq 8$ & 0 & 0.0 & 0 & 0.0 & 1 \\
\hline Vancomycin & - & $\geq 1$ & 0 & 0.0 & 0 & 0.0 & 1 \\
\hline
\end{tabular}

${ }^{1}$ Per cow, only one isolate of the same bacterial species was tested.

${ }^{2}$ The breakpoints determining resistance were those recommended in the CLSI (Clinical and Laboratory Standards Institute) guidelines M31-A2 (CLSI, 2002) and M7-A6 (CLSI, 2003). Strains showing intermediate category were classified as resistant.

${ }^{3}$ Number of cows with Strep. uberis.

${ }^{4}$ Number of strains with antibiotic resistance.

${ }^{5}$ Significance levels of difference between cows in OP and farms with IP in the study from the Fisher's Exact Test statistic.

\section{Isolates and Tested Bacteria}

One hundred fifty-eight isolates of quarter milk samples (93 from OP and 65 from IP cows) from quarters diagnosed with a CMT $\geq 2+$ reaction were tested for antibiotic resistance. Of these, 79 isolates (46 from OP and 33 from IP cows) were identified as Staphylococcus aureus, 38 (19 OP, 19 IP) as nonaureus staphylococci, 28 (19 OP, 9 IP) as Streptococcus uberis, and 13 (9 OP, 4 IP) as Streptococcus dysgalactiae.

\section{Antibiotic Resistance of Staphylococcus aureus}

All Staphylococcus aureus strains (n = 79) were susceptible to amoxicillin-clavulanic acid and vancomycin

Table 4. Antibiotic resistance rates of Streptococcus dysgalactiae strains isolated from quarters with subclinical mastitis (California Mastitis Test $\geq 2$ ) at d 31 postpartum in 60 farms with organic production (OP) and 60 farms with integrated production (IP) ${ }^{1}$

\begin{tabular}{|c|c|c|c|c|c|c|c|}
\hline \multirow[b]{2}{*}{ Antibiotic substance } & \multicolumn{2}{|c|}{$\begin{array}{l}\text { Breakpoints }^{2} \\
(\mu \mathrm{g} / \mathrm{mL})\end{array}$} & \multicolumn{2}{|c|}{$\begin{array}{c}\mathrm{OP} \text { cows } \\
(\mathrm{n}=19)\end{array}$} & \multicolumn{2}{|c|}{$\begin{array}{c}\text { IP cows }{ }^{3} \\
(\mathrm{n}=9)\end{array}$} & \multirow[b]{2}{*}{$P^{5}$} \\
\hline & Intermediate & Resistant & No. ${ }^{4}$ & $\%$ & No. ${ }^{4}$ & $\%$ & \\
\hline Amoxicillin-clavulanic acid (2:1) & $16 / 8$ & $\geq 32 / 16$ & 0 & 0.0 & 0 & 0.0 & 1 \\
\hline Ceftiofur & 4 & $\geq 8$ & 0 & 0.0 & 0 & 0.0 & 1 \\
\hline Chloramphenicol & 8 & $\geq 16$ & 0 & 0.0 & 0 & 0.0 & 1 \\
\hline Clindamycin & 0.5 & $\geq 1$ & 0 & 0.0 & 2 & 50.0 & 0.08 \\
\hline Enrofloxacin & 1 to 2 & $\geq 4$ & 3 & 33.3 & 3 & 75.0 & 0.27 \\
\hline Erythromycin & 0.5 & $\geq 1$ & 0 & 0.0 & 2 & 50.0 & 0.08 \\
\hline Gentamicin & 8 & $\geq 16$ & 2 & 22.2 & 1 & 25.0 & 1 \\
\hline Penicillin & 2 & $\geq 4$ & 0 & 0.0 & 1 & 25.0 & 0.31 \\
\hline Quinpristin-dalfopristin & 0.25 to 2 & $\geq 4$ & 0 & 0.0 & 0 & 0.0 & 1 \\
\hline Tetracycline & 4 & $\geq 8$ & 5 & 55.6 & 4 & 100.0 & 0.23 \\
\hline Vancomycin & - & $\geq 1$ & 0 & 0.0 & 0 & 0.0 & 1 \\
\hline
\end{tabular}

${ }^{1}$ Per cow, only one isolate of the same bacterial species was tested.

${ }^{2}$ The breakpoints determining resistance were those recommended in the CLSI (Clinical and Laboratory Standards Institute) guidelines M31-A2 (CLSI, 2002) and M7-A6 (CLSI, 2003). Strains showing intermediate category were classified as resistant.

${ }^{3}$ Number of cows with Staph. dysgalactiae.

${ }^{4}$ Number of strains with antibiotic resistance.

${ }^{5}$ Significance levels of difference between cows in OP and farms with IP in the study from the Fisher's Exact Test statistic. 
(Table 1). The percentage of resistance to enrofloxacin in isolates from IP and OP farms was not different. Resistance percentages to chloramphenicol, gentamicin, and penicillin were not different in isolates from OP and IP cows. Resistance to ceftiofur, clindamycin, erythromycin, oxacillin, quinupristin-dalfopristin, and tetracycline was found only in isolates from OP cows.

\section{Antibiotic Resistance of Nonaureus Staphylococci}

All nonaureus Staphylococcus isolates $(\mathrm{n}=38)$ were susceptible to amoxicillin-clavulanic acid, ceftiofur, enrofloxacin, and vancomycin (Table 2). Resistance percentages to oxacillin and penicillin were not different in isolates from IP and from OP cows. Resistance to chloramphenicol, gentamicin, quinupristin-dalfopristin, and tetracycline was only found in isolates from OP cows. On the other hand, resistance to erythromycin was only observed in strains from IP cows. The resistance percentage to clindamycin in isolates from both OP and IP cows was not different.

\section{Antibiotic Resistance of Streptococcus uberis}

All isolates $(\mathrm{n}=28)$ were susceptible to amoxicillinclavulanic acid, ceftiofur, tetracycline, and vancomycin (Table 3). Resistance percentages to chloramphenicol, enrofloxacin, gentamicin, and penicillin were not different in isolates from OP than from IP cows. Resistance to clindamycin, erythromycin, and quinupristin-dalfopristin was only found in strains from OP cows.

\section{Antibiotic Resistance of Streptococcus dysgalactiae}

All isolates ( $n=13)$ were susceptible to amoxicillinclavulanic acid, ceftiofur, chloramphenicol, quinupristin-dalfopristin, and vancomycin (Table 4). Resistance percentages to enrofloxacin, gentamicin, and tetracycline were not different in isolates from IP or OP farms. Resistance to clindamycin, erythromycin, and penicillin was only observed in isolates from IP cows.

\section{Single and Multiple Resistances}

Multidrug resistances against up to 8 different antibiotic agents were observed; however, the isolates of the 4 bacterial groups tested were most frequently resistant against just 1 or 2 antibiotics (Table 5). The resistance percentages were not significantly different among bacterial strains isolated from OP and IP cows with the exception of Streptococcus uberis isolates, which exhibited more single resistances (compared with no resistance) when isolated from cows kept on OP farms than on IP farms ( 6 of 10 isolates vs. 0 of 5 isolates, respectively; $P=0.044$ ).

\section{DISCUSSION}

\section{General Aspects}

The farms selected in the present study allowed comparison of the antibiotic resistance of mastitis pathogens in OP and IP farms, without major local and geographical bias. The 12 antibiotics tested are representatives of the classes of antibiotics used to treat mastitis in dairy farms (aminoglycosides, cephalosporins, macrolides, lincosamides, $\beta$-lactams combined with or without $\beta$-lactamase inhibitor), or are important antibiotics used in human medicine (cephalosporins, fluoroquinolones, clindamycin, erythromycin, quinupristin-dalfopristin, gentamicin, penicillin, tetracyclines, vancomycin). In Switzerland, antibiotics like vancomycin, quinupristin-dalfopristin, erythromycin, clindamycin, fluoroquinolones, and chloramphenicol are not legally authorized for intramammary treatment or for use in food-producing animals in general, with the exception of fluoroquinolones, which are approved for nonintramammary treatment in cattle. However, antibiotics of the same classes as erythromycin (spiramycin) and clindamycin (lincomycin) are found in preparations used for mastitis treatment, and may select for cross-resistance. Therefore, these antibiotics relevant in human medicine were tested to evaluate the resistance situation against such nonauthorized drugs in mastitis pathogens. In addition, oxacillin was used to detect methicillin-resistant Staphylococcus aureus strains, which have emerged in Swiss health care institutes (Blanc et al., 2002). The tested groups of bacteria, which included Staphylococcus aureus, nonaureus staphylococci, Streptococcus uberis, and Streptococcus dysgalactiae, are the predominant etiological agents in subclinical mastitis of dairy cows (Myllys et al., 1998).

The main antibiotic agents used in dry cow therapy formulas in OP and IP farms were penicillin (40 and $66 \%$, respectively), cloxacillin (36.5 and $37 \%$, respectively), neomycin (23.5 and $52.7 \%$, respectively), and gentamicin (11.8 and 2.4\%, respectively) (M. Roesch, M. G. Doherr, and J. W. Blum, University of Bern, unpublished data). No preparation used during this study contained spiramycin, ceftiofur, or amoxicillin, as expected. In accordance with the guidelines for Swiss OP farms, the prophylactic use of antibiotic agents in OP farms was lower than in IP farms. This measure should lead to a lower development of antibiotic resistance because a close relationship was found between levels of antibiotic resistance and the exposition to the used antibiotics (Lopez-Lozano et al., 2000).

\section{Antibiotic Resistance of Staphylococcus aureus}

Despite a lower prophylactic and therapeutic administration of antibiotics in OP than IP cows, the number 
Table 5. Antimicrobial resistance, single- and multidrug-resistance frequencies of bacterial strains isolated from cows with subclinical mastitis (California Mastitis Test $\geq 2$ ) at d 31 postpartum in 60 farms with organic production (OP) and 60 farms with integrated production (IP)

\begin{tabular}{|c|c|c|c|c|c|c|c|c|}
\hline \multirow{2}{*}{$\begin{array}{l}\text { Number } \\
\text { of resistance } \\
\text { strains }\end{array}$} & \multicolumn{2}{|c|}{$\begin{array}{l}\text { Staphylococcus } \\
\text { aureus }\end{array}$} & \multicolumn{2}{|c|}{$\begin{array}{c}\text { Nonaureus } \\
\text { Staphylococcus spp. }\end{array}$} & \multicolumn{2}{|c|}{$\begin{array}{c}\text { Streptococcus } \\
\text { uberis }\end{array}$} & \multicolumn{2}{|c|}{$\begin{array}{l}\text { Streptococcus } \\
\text { dysgalactiae }\end{array}$} \\
\hline & OP (46) & IP (33) & OP (19) & IP (19) & OP (19) & IP (9) & OP (19) & IP (9) \\
\hline 0 & 30 & 27 & 10 & 9 & 4 & 5 & 3 & 0 \\
\hline 1 & 8 & 5 & 5 & 2 & 6 & 0 & 3 & 1 \\
\hline 2 & 5 & 1 & 1 & 7 & 6 & 0 & 2 & 1 \\
\hline 3 & 1 & 0 & 2 & 1 & 2 & 0 & 1 & 0 \\
\hline 4 & 0 & 0 & 1 & 0 & 0 & 4 & 0 & 1 \\
\hline 5 to 8 & 2 & 0 & 0 & 0 & 1 & 0 & 0 & 1 \\
\hline$\geq 1$ resist. & 16 & 6 & 9 & 10 & 15 & 4 & 6 & 4 \\
\hline $\begin{array}{l}\text { No vs. } \geq 1 \text { resistances } \\
\text { No vs. } 1 \text { resistance }\end{array}$ & \multicolumn{2}{|c|}{$P^{1}=0.13$} & \multicolumn{2}{|c|}{$P=1.00$} & \multicolumn{2}{|c|}{$\begin{array}{l}P=0.10 \\
P=0.044\end{array}$} & \multicolumn{2}{|c|}{$\begin{array}{l}P=0.50 \\
P=1.00\end{array}$} \\
\hline
\end{tabular}

${ }^{1}$ Significance levels of the differences between OP and IP cows were generated using Fisher's Exact Test.

of resistant Staphylococcus aureus strains toward antibiotic agents was slightly higher in isolates from OP than IP cows ( 35 and $18 \%$, respectively). The frequency of antibiotic resistance of isolates from OP than IP cows was in contrast to a recent study that reported a lower resistance percentage of Staphylococcus aureus mastitis isolates from certified organic dairy farms to antimicrobial agents in the United States (Tikofsky et al., 2003). The percentage of penicillin-resistant Staphylococcus aureus strains remained low in our isolates, although penicillin is one of the most frequently used antimicrobial agents for the treatment of udder infections. The higher number of multidrug-resistant Staphylococcus aureus strains in OP than in IP farms (although not significant) was unexpected. There was still a high level of chloramphenicol-resistant Staphylococcus aureus strains, especially in OP farms, although its use for food-producing animals has been banned in Switzerland since January 2001.

\section{Antibiotic Resistance of Nonaureus Staphylococci}

Nonaureus staphylococci had a higher percentage of antibiotic resistance than Staphylococcus aureus, which was in agreement with previously reported data of Corti et al. (2003). The number of nonaureus staphylococci that showed resistance to at least one antibiotic was higher than that described by Rajala-Schultz et al. (2004). This might be because those authors investigated a higher number of primiparous cows, whose bacterial flora from mammary glands exhibit fewer antibiotic resistances, especially against penicillin. The values for penicillin resistance of OP as well as in IP strains were higher than those reported by Busato et al. (2000; $13 \%)$, but comparable to Corti et al. (2003; $31 \%)$ and Rajala-Schultz et al. (2004; 32\%). However, resistances were lower than described in other European and US studies (Owens et al., 1997; Myllys et al., 1998).

\section{Antibiotic Resistance of Streptococcus uberis}

The number of tested Streptococcus uberis isolates was very small. Higher antibiotic resistance percentages for most antibiotics, except penicillin, were found in isolates from OP cows than from IP cows. Numbers of gentamicin-resistant strains found in isolates from OP than from IP cows agree with previous studies conducted in Switzerland (Busato et al., 2000; Corti et al., 2003) and in Germany (Sobiraj et al., 1997). The percentages of antibiotic resistance against enrofloxacin agree with the results of Owens et al. (1997).

\section{Antibiotic Resistance of Streptococcus dysgalactiae}

In OP farms, the total number of antibiotic resistant Streptococcus dysgalactiae isolates (9) was lower than that of Streptococcus uberis (27). No tetracycline-resistant Streptococcus uberis strain was found in both IP and OP farms, whereas $50 \%$ of the Streptococcus dysgalactiae isolates displayed tetracycline resistance, supporting Guérin-Faublée et al. (2003) and Rossitto et al. (2002). In IP farms, the number of resistant Streptococcus dysgalactiae strains against several antibiotics (4) was also lower compared with Streptococcus uberis strains (9), but the number of isolates was too low to make any definite conclusions.

\section{CONCLUSIONS}

This study, based on a representative sample of the dairy cow population in the canton of Bern, Switzerland, allowed a direct comparison of the antimicrobial situation of mastitis pathogens isolated from OP and IP farms. The percentage of antibiotic resistance was not different among Staphylococcus aureus, Streptococcus uberis, or Streptococcus dysgalactiae isolates from OP than IP cows, except for $\beta$-lactam antibiotics. Of 
note, none of the strains was resistant to amoxicillinclavulanic acid and vancomycin. Overall, the frequency of antibiotic resistance did not differ between isolates from $\mathrm{OP}$ and IP cows, but differences were found among bacterial species. Resistance of these important pathogenic bacteria to quinupristin-dalfopristin was found infrequently, although these antimicrobial compounds are not allowed for use in farm animals. Multidrug resistance was not a large problem and there were no significant differences in multidrug resistance percentages between OP and IP cows. The lack of difference in percentage of antibiotic resistance of isolates from IP and OP farms (on which the use of antibiotics should be very restricted) was unexpected. However, ongoing monitoring is necessary to monitor the situation of antibiotic resistance in mastitis pathogens to avoid the emergence of multidrug-resistant bacteria in an environment where they are not expected, such as on OP farms.

\section{ACKNOWLEDGMENTS}

The study was supported by the Swiss Federal Veterinary Office (Liebefeld-Bern), the Swiss Federal Agricultural Office (Bern), UFA Med, Sursee/Fenaco (Bern), and Migros Genossenschaftsbund, Kulturprozent (Zürich). We thank Esther Homfeld for her great contributions to this project. We are grateful to Myriam Leu, Lorianne Vorlet-Fawer, Elinor Goldschmidt-Clermont, and Sandra Brunner for their assistance in laboratory procedures. In addition, we thank the participating farmers for their support.

\section{REFERENCES}

Bates, J., J. Z. Jordens, and D. T. Griffiths. 1994. Farm animals as a putative reservoir for vancomycin-resistant enterococcal infections in man. J. Antimicrob. Chemother. 34:507-514.

Blanc, D. S., D. Pittet, C. Ruef, A. F. Widmer, K. Mühlemann, C. Petignat, S. Harbarth, R. Auckenthaler, J. Bille, R. Frei, R. Zbinden, R. Peduzzi, V. Gaia, H. Khamis, E. Bernasconi, and P. Francioli. 2002. Epidemiology of methicillin-resistant Staphylococcus aureus: Results of a nation-wide survey in Switzerland. Swiss Med. Wkly. 132:223-229.

Busato, A., P. Trachsel, M. Schallibaum, and J. W. Blum. 2000. Udder health and risk factors for subclinical mastitis in organic dairy farms in Switzerland. Prev. Vet. Med. 44:205-220.

Chaslus-Dancla, E., J. P. Lafont, and J. L. Martel. 2000. Spread of resistance from food animals to man: The French experience. Acta Vet. Scand. 93:53-61.

Clinical and Laboratory Standards Institute (CLSI). 2002. Performance standards for antimicrobial disk and dilution susceptibility tests for bacteria isolated from animals. Vol. 22, No. 6. 2nd ed. Approved standard M31-A2. National Committee for Clinical Laboratory Standards, Wayne, PA.

Clinical and Laboratory Standards Institute (CLSI). 2003. Methods for dilution antimicrobial susceptibility tests for bacteria that grow aerobically. Vol. 23, No. 2. 6th ed. Approved standard M7A6. National Committee for Clinical Laboratory Standards, Wayne, PA.
Corti, S., D. Sicher, W. Regli, and R. Stephan. 2003. Aktuelle Daten zur Antibiotikaresistenz der wichtigsten bovinen Mastitiserreger in der Schweiz. Schweiz. Arch. Tierheilkd. 145:571-575.

De Oliveira, A. P., J. L. Watts, S. A. Salmon, and F. M. Aarestrup. 2000. Antimicrobial susceptibility of Staphylococcus aureus isolated from bovine mastitis in Europe and the United States. J. Dairy Sci. 83:855-862.

Devriese, L. A., F. Haesebrouck, J. Hommez, and R. Vandermeersch. 1997. A 25-year survey of antibiotic susceptibility testing in Staphylococcus aureus from bovine mastitis in Belgium, with special reference to penicillinase. Vlaams Diergeneeskundig Tijdschr. 66:170-173.

Eberhart, R. J. 1986. Management of dry cows to reduce mastitis. J. Dairy Sci. 69:1721-1732.

Erskine, R. J., R. D. Walker, C. A. Bolin, P. C. Bartlett, and D. G. White. 2001. Trends in antibacterial susceptibility of mastitis pathogens during a seven-year period. J. Dairy Sci. 85:1111-1118.

Falkow, S., and D. Kennedy. 2001. Antibiotics, animals, and peopleagain! Science 291:397.

Guérin-Faublée, V., G. Carret, and P. Houffschmitt. 2003. In vitro activity of 10 antimicrobial agents against bacteria isolated from cows with clinical mastitis. Vet. Rec. 152:466-471.

Hillerton, J. E., and E. A. Berry. 2005. Treating mastitis in the cowa tradition or an archaism. J. Appl. Microbiol. 98:1250-1255.

International Dairy Federation. 1995. Enumeration of somatic cells. IDF Standard no. 148A. International Dairy Federation, Brussels, Belgium.

Levy, S. B. 1998. The challenge of antibiotic resistance. Sci. Am. 278:46-53.

Lopez-Lozano, J. M., D. L. Monnet, A. Yagüe, A. Burgos, N. Gonzalo, P. Lampillos, and M. Saez. 2000. Modelling and forecasting antimicrobial resistance and its dynamic relationship to antimicrobial use: A time series analysis. Int. J. Antimicrob. Agents 14:21-31.

Makovec, J. A., and P. Ruegg. 2003. Antimicrobial resistance of bacteria isolated from dairy cow milk samples submitted for bacterial culture: 8905 samples (1994-2001). J. Am. Vet. Med. Assoc. 222:1582-1589.

Moellering, R. C. 1990. Interaction between antimicrobial consumption and selection of resistant bacterial strains. Scand. J. Infect. Dis. (Suppl.) 70:18-24.

Myllys, V., K. Asplund, E. Brofeldt, V. Hirvela-Koski, T. HonkanenBuzalski, J. Junttila, L. Kulkas, O. Myllykangas, M. Niskanen, H. Saloniemi, M. Sandholm, and T. Saranpaa. 1998. Bovine mastitis in Finland in 1988 and 1995-Changes in prevalence and antimicrobial resistance. Acta Vet. Scand. 39:119-126.

NMC. 1999. Laboratory Handbook on Bovine Mastitis. Rev. Ed. National Mastitis Council Inc., Madison, WI.

NMC. 2004 Bovine mastitis pathogens and trends in resistance to antimicrobial drugs. National Mastitis Council Research Committee Report. Pages 440-414 in Proc. 43rd Annu. Mtg. NMC, Charlotte, NC. National Mastitis Council, Madison, WI.

Owens, W. E., C. H. Ray, J. L. Watts, and R. J. Yancey. 1997. Comparison of success of antibiotic therapy during lactation and results of antimicrobial susceptibility tests for bovine mastitis. J. Dairy Sci. 80:313-317.

Pitkälä, A., M. Haveri, S. Pyörälä, V. Myllys, and T. HonkanenBuzalski. 2004. Bovine mastitis in Finland 2001-prevalence, distribution of bacteria, and antimicrobial resistance. J. Dairy Sci. 87:2433-2441.

Rajala-Schultz, P. J., K. L. Smith, J. S. Hogan, and B. C. Love. 2004. Antimicrobial susceptibility of mastitis pathogens from first lactation and older cows. Vet. Microbiol. 102:33-42.

Roesch, M. 2004. Dairy cows in Swiss organic and conventional farms: Comparison of management, feeding, production, reproduction and udder health. Med. Vet. Thesis, Veterinary Faculty, University of Bern, Switzerland.

Roesch, M., M. Doherr, and J. W. Blum. 2005. Performance of dairy cows on Swiss farms with organic and integrated production. J. Dairy Sci. 88:2462-2475.

Rossitto, P. V., L. Ruiz, Y. Kikuchi, K. Glenn, K. Luiz, J. L. Watts, and J. S. Cullor. 2002. Antibiotic susceptibility patterns for envi- 
ronmental streptococci isolated from bovine mastitis in central California dairies. J. Dairy Sci. 85:132-138.

Salmon, S. A., J. L. Watts, J. A. Aarestrup, and J. R. Yancey, Jr. 1998. Minimum inhibitory concentrations for selected antimicrobial agents against organism isolated from mammary glands of dairy heifers in New Zealand and Denmark. J. Dairy Sci. 81:570-578.

Sato, K., T. W. Bennedsgaard, P. C. Bertlett, R. J. Erskine, and J. B. Kaneene. 2004. Comparison of antimicrobial susceptibility of Staphylococcus aureus isolated from bulk tank milk in organic and conventional dairy herds in the midwestern United States and Denmark. J. Food Prot. 67:1104-1110.
Shea, K. M. 2003. Antibiotic resistance: What is the impact of agricultural uses of antibiotics on children's health? Pediatrics 112:253-258.

Sobiraj, A., A. Kron, U. Schollmeyer, and K. Failing. 1997. Bundesweite Untersuchung zur Erregerverteilung und in-vitro Resistenz euterpathogener Bakterien in der Milch von Kühen mit subklinischer Mastitis. Tierarztl. Prax. 25:108-115.

Tikofsky, L. L., J. W. Barlow, C. Santisteban, and Y. H. Schukken. 2003. A comparison of antimicrobial susceptibility patterns for Staphylococcus aureus in organic and conventional dairy herds. Microb. Drug Resist. 9(Suppl. 1):S39-S45.

Witte, W. 1998. Medical consequences of antibiotic use in agriculture. Science 279:996-997. 